\title{
Effect of feeding a negative dietary cation-anion difference diet for an extended time prepartum on postpartum serum and urine metabolites and performance
}

\author{
Z. Wu, ${ }^{* 1}$ J. K. Bernard, ${ }^{* 2}$ K. P. Zanzalari, $†$ and J. D. Chapman† \\ *University of Georgia, Animal and Dairy Science Department, Tifton 31793 \\ †Prince Agri Products Inc., Quincy, IL
}

\begin{abstract}
Forty-five multiparous Holstein cows and 15 springing Holstein heifers were used in a randomized block design trial to determine the effect of length of feeding a negative dietary anion-cation difference (DCAD) diet prepartum on serum and urine metabolites, dry matter (DM) intake, and milk yield and composition. After training to eat through Calan doors (American Calan Inc., Northwood, NH), cows within parity were assigned randomly to 1 of 3 treatments and fed a negative-DCAD diet for $3(3 \mathrm{~W}), 4(4 \mathrm{~W})$, or $6 \mathrm{wk}(6 \mathrm{~W})$ before predicted calving. Actual days cows were fed negative-DCAD diets was $19.2 \pm 4.1,27.9 \pm 3.1$, and $41.5 \pm 4.1 \mathrm{~d}$ for $3 \mathrm{~W}, 4 \mathrm{~W}$, and $6 \mathrm{~W}$, respectively. Before the trial, all cows were fed a high-forage, low-energy diet. During the trial, cows were fed a diet formulated for late gestation $(14.6 \% \mathrm{CP}, 42.3 \% \mathrm{NDF}, 20.5 \%$ starch, $7.1 \%$ ash, and $0.97 \% \mathrm{Ca}$ ) supplemented with Animate (Prince Agri Products Inc., Quincy, IL), with a resulting DCAD $(\mathrm{Na}+\mathrm{K}-\mathrm{Cl}-\mathrm{S})$ of $-21.02 \mathrm{mEq} / 100 \mathrm{~g}$ of DM. After calving, cows were fed a diet formulated for early lactation $(18.0 \% \mathrm{CP}, 36.4 \% \mathrm{NDF}, 24.2 \%$ starch, $8.1 \%$ ash, and $0.94 \% \mathrm{Ca}$ ) for the following $6 \mathrm{wk}$ with a DCAD of $20.55 \mathrm{mEq} / 100 \mathrm{~g}$ of DM. Urine $\mathrm{pH}$ was not different among treatments before calving and averaged 6.36. No differences were observed in prepartum DM intake, which averaged $11.4,11.5$, and $11.7 \mathrm{~kg} / \mathrm{d}$ for $3 \mathrm{~W}, 4 \mathrm{~W}$, and $6 \mathrm{~W}$, respectively. Prepartum serum total protein, albumin, and $\mathrm{Ca}$ concentrations, and anion gap were within normal limits but decreased linearly with increasing time cows were fed a negative-DCAD diet. No differences were observed in serum metabolite concentrations on the day of calving. Postpartum, serum total protein and globulin concentrations increased linearly with increasing length of time the negative-
\end{abstract}

Received April 22, 2014

Accepted August 4, 2014.

${ }^{1}$ Current address: Phibro Animal Health Corp., 300 Frank W. Burr Blvd., Ste 21, Teaneck, NJ 07666-6712.

${ }^{2}$ Corresponding author: jbernard@uga.edu
DCAD diet was fed. No differences were observed in postpartum DM intake, milk yield, or concentration of fat or protein among treatments: $19.1 \mathrm{~kg} / \mathrm{d}, 40.6 \mathrm{~kg} / \mathrm{d}$, $4.30 \%$, and $2.80 \% ; 19.6 \mathrm{~kg} / \mathrm{d}, 41.5 \mathrm{~kg} / \mathrm{d}, 4.50 \%$, and $2.90 \%$; and $18.6 \mathrm{~kg} / \mathrm{d}, 41.0 \mathrm{~kg} / \mathrm{d}, 4.30 \%$, and $2.73 \%$ for $3 \mathrm{~W}, 4 \mathrm{~W}$, and $6 \mathrm{~W}$, respectively. Results of this trial indicate that no differences existed in health or milk production or components in cows fed a negative-DCAD diet for up to 6 wk prepartum compared with those fed a negative-DCAD diet for 3 or 4 wk prepartum.

Key words: dietary cation-anion difference, milk yield, milk composition

\section{INTRODUCTION}

The transition from late gestation to lactation requires enormous physiological adaptations by the dairy cow, which can significantly affect the following lactation and subsequent reproduction. Nutrition management during the transition period is challenged by reduced DMI during the late-gestation period coupled with a drastic increase in nutrient requirements following calving. One of the most significant challenges involves $\mathrm{Ca}$ homeostasis and can result in clinical or subclinical hypocalcaemia. Block (1984) reported that cows experiencing clinical hypocalcaemia during the immediate periparturient period produced $14 \%$ less milk than cows with normal serum Ca concentrations. In addition to decreased milk yield, cows that experienced clinical or subclinical hypocalcaemia are at greater risk for developing other metabolic disorders (Curtis et al., 1985). Feeding negative DCAD diets prepartum stimulated Ca absorption and mobilization, thus preventing hypocalcaemia, and maintained DMI and improved milk yield postpartum (Block, 1984; DeGroot et al., 2010).

Animate (Prince Agri Products Inc., Quincy, IL) is an anionic mineral supplement containing (\% of DM), $13.9 \% \mathrm{Cl}, 5.4 \% \mathrm{~S}, 4.8 \% \mathrm{Mg}$, and $39.0 \% \mathrm{CP}$ that is designed for use in close-up dry cow diets to acidify the diet, reducing the incidence of clinical and subclinical hypocalcaemia, resulting in greater DMI and milk yield postpartum (Puntenney, 2006). Feeding a 
negative-DCAD diet starting $21 \mathrm{~d}$ prepartum was shown to be effective in preventing hypocalcaemia (Chan et al., 2006; DeGroot et al., 2010). Degaris et al. (2008) reported increased ECM and milk protein yield postpartum when cows were fed prepartum transition diets with a DCAD of $-15 \mathrm{mEq} / 100 \mathrm{~g}$ for 25 and $22 \mathrm{~d}$ prepartum, respectively. Most studies have focused on the effect of feeding variable levels of DCAD, whereas limited research has been conducted on the length of feeding a DCAD diet to transition cows. The objective of this study was to evaluate the effects of length of time feeding a negative-DCAD diet prepartum on serum metabolites and performance postpartum.

\section{MATERIALS AND METHODS}

Forty-five dairy cows and 15 primiparous Holstein heifers were used in a randomized block design trial starting $21 \pm 3,28 \pm 3$, or $42 \pm 3$ d prepartum. Cows were assigned to treatment based on expected calving date and parity. Because some cows calved earlier or later than expected, treatment assignments were based on days fed the negative-DCAD diet according to actual calving date and was defined as less than $24 \mathrm{~d}(\mathbf{3} \mathbf{W})$, 25 to $34 \mathrm{~d}(\mathbf{4} \mathbf{W})$, or longer than $36 \mathrm{~d}(\mathbf{6 W})$ providing 23,18 , and 18 animals for each treatment, respectively. One primiparous cow was removed from the trial because of a breech birth. All protocols were approved by the University of Georgia Institutional Animal Care and Use Committee (Tifton).

Prior to beginning the trial, cows were fed a highfiber, low-energy diet based on bermudagrass baleage, corn silage, and supplemental concentration to meet NRC (2001) requirements for protein, minerals, and vitamins. Before beginning the trial, cows were trained to eat through Calan doors (American Calan Inc., Northwood, NH). Cows were housed in a freestall barn equipped with fans and misters and were allowed unlimited access to an exercise lot. Cows were moved to either the grassed lot or a box stall at calving and returned to the freestall area after calving.

Experimental diets were formulated to meet NRC (2001) requirements for late gestation and early lactation (Table 1). Animate (anionic mineral supplement; Prince Agri Products Inc., Quincy, IL) was included in the late-gestation diet as an acidifying agent. The amount fed was adjusted after measuring urinary $\mathrm{pH}$ to maintain a $\mathrm{pH}$ within the range of 6.0 to 6.5 during the first days of the trial. Once the amount required to achieve the desired $\mathrm{pH}$ was determined, the amount fed was maintained throughout the trial as outlined in Table 1. Experimental diets were mixed and fed once daily using a DataRanger mixer (American Calan Inc.). Cows had free access to water throughout the day. The
Table 1. Ingredient composition of experimental diets (\% of DM)

\begin{tabular}{|c|c|c|}
\hline \multirow[b]{2}{*}{ Ingredient } & \multicolumn{2}{|c|}{ Diet } \\
\hline & Prepartum & Postpartum \\
\hline Corn silage & 42.86 & 35.59 \\
\hline Alfalfa hay & 5.95 & \\
\hline Ryegrass baleage & & 9.79 \\
\hline Bermudagrass baleage & 7.94 & \\
\hline Whole cottonseed & & 8.90 \\
\hline Ground corn & 8.93 & 16.55 \\
\hline Brewers grains, wet & 7.94 & 12.46 \\
\hline Citrus pulp & 3.97 & 4.45 \\
\hline Soybean hulls (pelleted) & 7.94 & \\
\hline Animate $^{1}$ & 4.56 & \\
\hline Soybean meal $(48 \% \mathrm{CP})$ & 5.95 & 3.56 \\
\hline AminoPlus $^{2}$ & & 1.78 \\
\hline Prolak $^{3}$ & 0.79 & 3.20 \\
\hline Sodium bicarbonate & & 0.89 \\
\hline Magnesium oxide & 0.16 & 0.36 \\
\hline Calcium carbonate & 1.19 & 1.07 \\
\hline Salt & & 0.18 \\
\hline Potassium carbonate & & 0.27 \\
\hline Yeast culture & 0.50 & 0.22 \\
\hline Trace mineral & 0.14 & 0.14 \\
\hline Vitamin E & 0.14 & 0.02 \\
\hline Rumensin $(3 \mathrm{~g} / \mathrm{lb})^{4}$ & 0.48 & 0.34 \\
\hline Zinpro Availa-4 $4^{5}$ & 0.08 & 0.04 \\
\hline OmniGen-AF ${ }^{6}$ & 0.50 & 0.22 \\
\hline
\end{tabular}

${ }^{1}$ Anionic mineral supplement, Prince Agri Products Inc. (Quincy, IL).

${ }^{2}$ Ruminally protected soybean meal (Ag Processing Inc. Omaha, NE).

${ }^{3}$ Marine and animal rumen-undegradable protein supplement (H. J. Baker \& Bro. Inc. Westport, CT).

${ }^{4}$ Elanco Animal Health (Indianapolis, IN).

${ }^{5}$ Organic zinc, manganese, copper, and cobalt (Zinpro Corp., Eden Prairie, MN).

${ }^{6}$ Immune modulator (Prince Agri Products Inc.).

amount of feed provided was adjusted to maintain a minimum of $5 \%$ refusal. The amount of feed offered and refused was recorded daily.

Samples of dietary ingredients, TMR, and orts were collected $3 \mathrm{~d}$ each week and analyzed for DM content by drying samples at $50^{\circ} \mathrm{C}$ for $48 \mathrm{~h}$ in a forced-air oven. Individual samples were ground to pass through a $6-\mathrm{mm}$ screen using a Wiley mill (Thomas Scientific, Swedesboro, NJ), and composited by week. A subsample was ground to pass through a 1-mm screen before analysis of ash (AOAC International, 2000), N (Leco FP-528 Nitrogen Analyzer; Leco Corp., St. Joseph, MO), NDF (Van Soest et al., 1991), ADF (AOAC International, 2000), starch (Hall, 2009), sugar (DuBois et al., 1956), and ether extract and minerals (AOAC International, 2000).

After calving, cows were milked 3 times daily beginning at 0000, 0800, and $1600 \mathrm{~h}$. Milk weights were recorded electronically at each milking (Alpro; DeLaval Inc., Kansas City, MO), totaled each day, and a weekly average calculated. Milk samples were collected from 3 consecutive milkings each week for analysis of fat, protein, lactose, SNF, and MUN concentrations by 
mid-infrared spectrophotometric analysis with a Foss 4000 instrument (Foss North America, Eden Prairie, MN; Dairy One Cooperative, Ithaca, NY).

Body weight of cows were recorded on 3 consecutive days during -3 wk prepartum and wk 3 and 6 postpartum and once immediately after parturition. Access to water and feed was restricted until measurements were recorded. Body condition scores were assigned at the same time by 2 individuals on a 1 to 5 scale as described by Wildman et al. (1982).

Two whole-blood samples were collected from the coccygeal vessels at $0900 \mathrm{~h}$ once during wk $-6,-5,-4,-3$, -2 , and -1 prepartum, at calving, and during wk 1,2 , 3 , and 6 postpartum. One sample was used for determination of serum glucose, urea $\mathrm{N}$, total protein, albumin, creatinine, total bilirubin, aspartate aminotransferase (AST), creatine kinase, $\gamma$-glutamyl transferase (GGT), $\mathrm{Ca}, \mathrm{P}, \mathrm{Mg}, \mathrm{Na}, \mathrm{K}, \mathrm{Cl}$, and bicarbonate concentrations, and anion gap, using a Boehringer Mannheim/Hitachi 912 automated chemistry analyzer (Roche Laboratory Systems, Indianapolis, IN). Bicarbonate concentrations were determined using enzymatic methods based on phosphoenolpyruvate carboxylase-catalyzed reaction of $\mathrm{HCO}_{3}{ }^{-}$with phosphoenolpyruvate to produce oxaloacetate. Malate dehydrogenase was used to catalyze the indicator reaction. Serum was separated from the second sample and analyzed for NEFA concentration using an enzymatic procedure (Waco Chemicals USA Inc., Richmond, VA). Serum BHBA concentrations were determined using Nova Max Ketone Strips and a Nova Max Plus reader (Nova Biomedical Corp., Waltham, MA). Urine samples were collected at the same times for analyses for $\mathrm{pH}$ and electrolyte concentrations as described above.

Data were analyzed using PROC MIXED of SAS (SAS Enterprise 4.2; SAS Institute Inc., Cary, NC). The model included block, treatment, week, and their interactions. Genetic merit (PTA of multiparous cows and ETA of springing heifers) was included as a covariate for production variables. Contrast statements were included in the model to evaluate linear and quadratic effects of treatment. Cow within treatment was included as a random effect and week as a repeated measure. Significance was declared at $P<0.05$ and trends at $0.05<P<0.10$.

\section{RESULTS AND DISCUSSION}

The chemical composition of experimental diets is presented in Table 2. Nutrient concentrations in each of the diets were consistent with formulated values. The DCAD $[(\mathrm{Na}+\mathrm{K})-(\mathrm{Cl}+\mathrm{S})]$ of the prepartum and postpartum diets were -21.02 and $20.55 \mathrm{mEq} / 100 \mathrm{~g}$, respectively.
Table 2. Chemical composition of experimental diets

\begin{tabular}{|c|c|c|}
\hline \multirow[b]{2}{*}{ Item } & \multicolumn{2}{|c|}{ Diet } \\
\hline & Prepartum & Postpartum \\
\hline $\mathrm{DM}, \%$ & $52.6 \pm 3.0$ & $50.2 \pm 3.3$ \\
\hline \multicolumn{3}{|l|}{ Ingredient, $\%$ of DM } \\
\hline $\mathrm{CP}$ & $14.6 \pm 1.0$ & $18.0 \pm 0.9$ \\
\hline $\mathrm{ADF}$ & $26.2 \pm 1.9$ & $21.6 \pm 1.4$ \\
\hline NDF & $42.3 \pm 2.3$ & $36.4 \pm 1.9$ \\
\hline Starch & $20.5 \pm 2.3$ & $24.2 \pm 2.3$ \\
\hline Sugar & $2.8 \pm 0.5$ & $3.2 \pm 0.8$ \\
\hline Ether extract & $3.3 \pm 0.4$ & $5.0 \pm 0.5$ \\
\hline Ash & $7.1 \pm 0.8$ & $8.1 \pm 1.1$ \\
\hline $\mathrm{Ca}$ & $0.97 \pm 0.23$ & $0.94 \pm 0.16$ \\
\hline $\mathrm{P}$ & $0.37 \pm 0.04$ & $0.51 \pm 0.02$ \\
\hline $\mathrm{Mg}$ & $0.52 \pm 0.10$ & $0.47 \pm 0.09$ \\
\hline $\mathrm{K}$ & $1.07 \pm 0.15$ & $1.30 \pm 0.10$ \\
\hline $\mathrm{S}$ & $0.42 \pm 0.09$ & $0.26 \pm 0.08$ \\
\hline $\mathrm{Na}$ & $0.08 \pm 0.04$ & $0.41 \pm 0.12$ \\
\hline $\mathrm{Cl}$ & $0.97 \pm 0.19$ & $0.45 \pm 0.17$ \\
\hline \multicolumn{3}{|l|}{$\mathrm{mEq} / 100 \mathrm{~g}$} \\
\hline $\mathrm{DCAD}^{1}$ & -21.02 & 20.55 \\
\hline $\mathrm{DCAD}^{2}$ & 3.98 & 39.3 \\
\hline
\end{tabular}

${ }^{1}$ Calculated as $(\mathrm{Na}+\mathrm{K})-(\mathrm{Cl}+\mathrm{S})$.

${ }^{2}$ Calculated as $\mathrm{Na}+\mathrm{K}-\mathrm{Cl}$.

\section{Prepartum Response}

Urine $\mathrm{pH}$ was maintained within the desired range prepartum (between 6.0 and 6.5) and averaged 6.44, 6.22 and 6.43 for $3 \mathrm{~W}, 4 \mathrm{~W}$, and $6 \mathrm{~W}$, respectively (Table 3 ; Figure 1). Prepartum urine $\mathrm{pH}$ is an important indicator of systemic acidification. One inconsistency in prepartum acidification research has been the large variation between and among studies with respect to level of systemic acidification. This difference may account for the different responses observed in serum metabolite concentrations and postpartum health and production responses between studies. Although no treatment $\times$ week interaction was detected, urine $\mathrm{pH}$ for $6 \mathrm{~W}$ cows tended to increase more during the final week of gestation than for cows fed either of the other 2 treatments. Weich et al. (2013) reported a rise in $\mathrm{pH}$ for cows fed a negative-DCAD diet for $42 \mathrm{~d}$ compared with $21 \mathrm{~d}$. However, the increase in urine $\mathrm{pH}$ began at wk -3 .

Prepartum DMI (either $\mathrm{kg} / \mathrm{d}$ or \% of BW) was not different $(P>0.10)$ among treatments and averaged $11.4,11.5$, and $11.7 \mathrm{~kg} / \mathrm{d}$ and $1.70,1.68$, and $1.73 \%$ of $\mathrm{BW}$ for $3 \mathrm{~W}, 4 \mathrm{~W}$, and $6 \mathrm{~W}$, respectively (Table 4 ). However, daily DMI was slightly higher for $3 \mathrm{~W}$ compared with $4 \mathrm{~W}$ on $\mathrm{d}-21$ and lower for $4 \mathrm{~W}$ compared with $3 \mathrm{~W}$ and $6 \mathrm{~W}$ on $\mathrm{d}-1$, resulting in a tendency $(P=$ $0.06)$ for an interaction of treatment by day prepartum (Figure 2).

Concentrations of select metabolites and minerals in serum and urine during wk -3 through -1 are presented in Table 3. Linear decreases were observed 


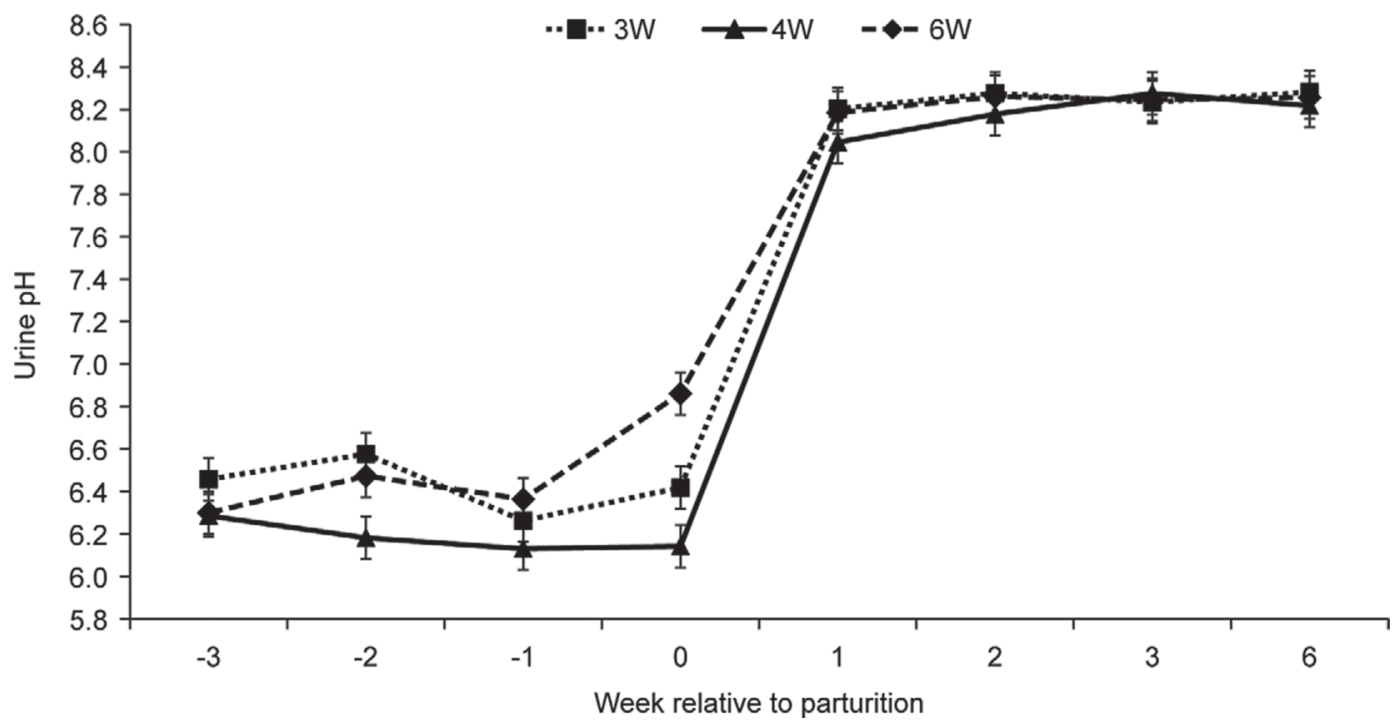

Figure 1. Urine $\mathrm{pH}$ of cows fed a negative-DCAD diet for $3(3 \mathrm{~W}), 4(4 \mathrm{~W})$, or $6 \mathrm{wk}(6 \mathrm{~W})$ prepartum and a positive-DCAD diet postpartum (treatment $\times$ week: $P>0.10$ ). Cows were fed negative-DCAD diets for 3 to $4 \mathrm{~d}$ before collection of the -3 -wk sample and urine pH for wk 0 was measured on the day of calving. Data represent least squares means \pm SEM.

in concentrations of serum total protein $(P=0.03)$, albumin $(P=0.01)$, Ca $(P=0.02)$, and $\mathrm{K}(P=0.07)$, and anion gap $(P=0.006)$ as time of feeding negativeDCAD diets increased. A quadratic response was observed prepartum for lower concentrations of serum $\mathrm{Na}(P=0.03)$ for $4 \mathrm{~W}$ compared with $3 \mathrm{~W}$ and $6 \mathrm{~W}$, which most likely reflects differences in urinary secretion of $\mathrm{Na}$, which was numerically higher for $4 \mathrm{~W}(P$

Table 3. Concentrations of select metabolites and minerals in serum and urine prepartum (wk -1 through -3 prepartum) in cows fed a negative-DCAD diet for $3(3 \mathrm{~W}), 4(4 \mathrm{~W})$, or $6 \mathrm{wk}(6 \mathrm{~W})$ prepartum

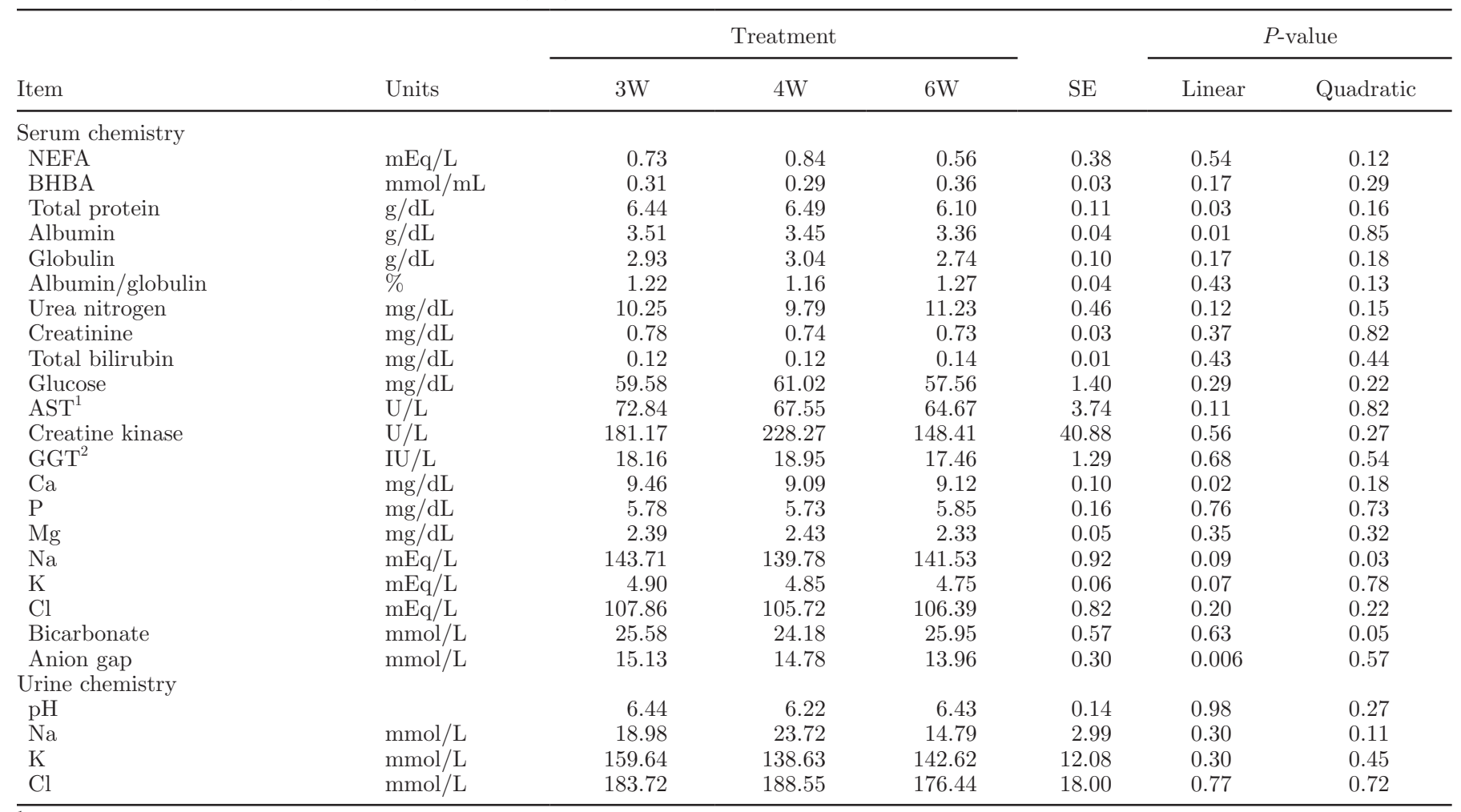

${ }^{1}$ Aspartate transaminase.

${ }^{2} \gamma$-Glutamyl transferase. 


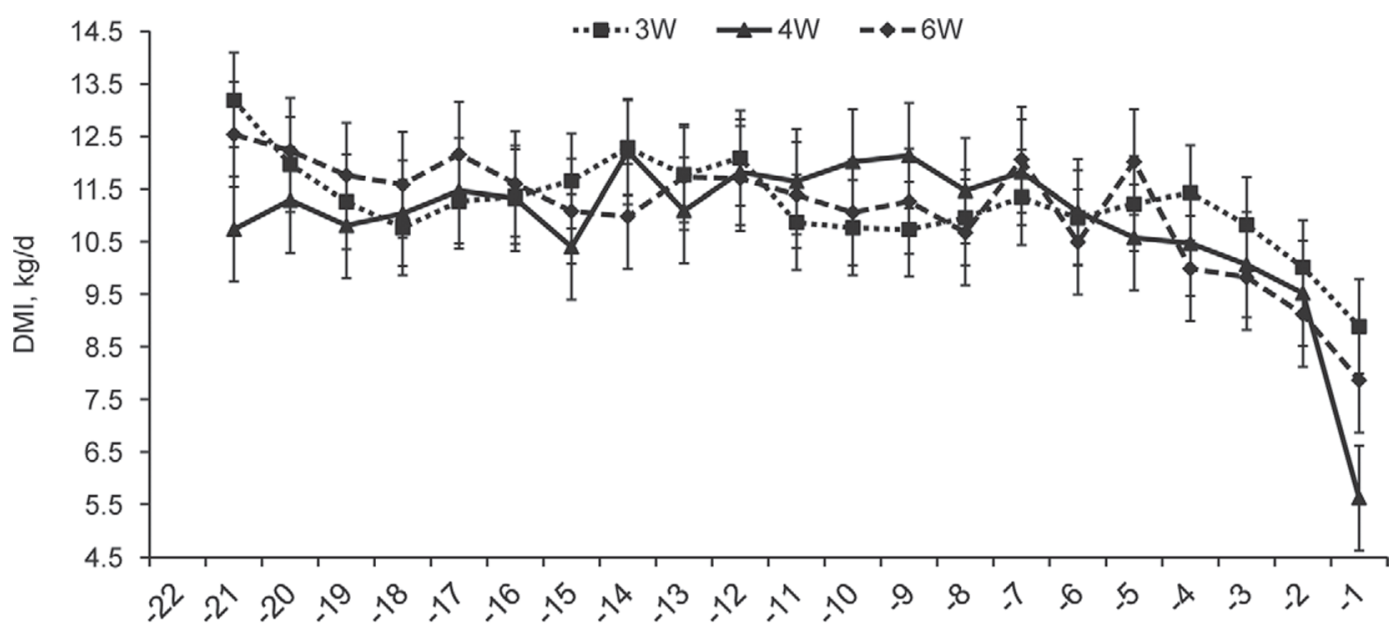

Day prepartum

Figure 2. Prepartum DMI of cows fed a negative-DCAD diet for $3(3 \mathrm{~W}), 4(4 \mathrm{~W})$, or 6 wk $(6 \mathrm{~W})$ prepartum (treatment $\times$ day: $P=0.06)$. Data represent least squares means \pm SEM.

$=0.11)$. A similar tendency for a quadratic response was observed for serum bicarbonate concentration $(P$ $=0.05)$, which reflects changes in acid-base balance to maintain homeostasis. No differences were observed in the remaining serum metabolites.

The linear increase observed in serum concentrations of total Ca and anion gap prepartum for $3 \mathrm{~W}$ compared with $4 \mathrm{~W}$ and $6 \mathrm{~W}$ are consistent with the linear increase in serum albumin concentrations. Albumin is a negatively charged protein that binds $\mathrm{Ca}$ and changes in albumin concentrations may alter total calcium concentrations (Payne et al., 1979). Payne et al. (1979) proposed adjusting total Ca concentrations for albumin concentrations to access changes in total Ca concentrations. When corrected for albumin concentrations, prepartum total Ca exhibited a trend for a linear decrease $(P=0.07)$ with increasing time that negative-DCAD diets were fed $(9.45,9.13$, and $9.22 \mathrm{mg} / \mathrm{dL}$ for $2 \mathrm{~W}, 4 \mathrm{~W}$, and $6 \mathrm{~W}$, respectively). Correction for albumin did not alter the response. Although serum Ca concentrations (unadjusted and adjusted) were lower for $4 \mathrm{~W}$ and $6 \mathrm{~W}$ compared with $3 \mathrm{~W}$, concentrations were within the normal range. Ionized $\mathrm{Ca}(\mathbf{i C a})$ is a more reliable indicator than total serum $\mathrm{Ca}$ to indicate biological effect of $\mathrm{Ca}$

Table 4. Dry matter intake and milk yield and composition of cows fed a negative-DCAD diet for 3 (3W), 4 $(4 \mathrm{~W})$, or $6 \mathrm{wk}(6 \mathrm{~W})$ prepartum

\begin{tabular}{|c|c|c|c|c|c|c|}
\hline \multirow[b]{2}{*}{ Item } & \multicolumn{3}{|c|}{ Treatment } & \multirow[b]{2}{*}{$\mathrm{SE}$} & \multicolumn{2}{|c|}{$P$-value } \\
\hline & $3 \mathrm{~W}$ & $4 \mathrm{~W}$ & $6 \mathrm{~W}$ & & Linear & Quadratic \\
\hline \multicolumn{7}{|c|}{ Prepartum DMI } \\
\hline $\mathrm{kg} / \mathrm{d}$ & 11.4 & 11.5 & 11.7 & 0.6 & 0.68 & 0.97 \\
\hline$\%$ of BW & 1.70 & 1.68 & 1.73 & 0.12 & 0.86 & 0.83 \\
\hline \multicolumn{7}{|c|}{ Postpartum DMI } \\
\hline $\mathrm{kg} / \mathrm{d}$ & 19.1 & 19.6 & 18.6 & 0.8 & 0.64 & 0.48 \\
\hline$\%$ of $\mathrm{BW}$ & 3.12 & 3.15 & 3.01 & 0.19 & 0.67 & 0.72 \\
\hline Milk, kg/d & 40.6 & 41.5 & 41.0 & 1.5 & 0.83 & 0.74 \\
\hline Fat, $\%$ & 4.30 & 4.50 & 4.30 & 0.13 & 0.98 & 0.27 \\
\hline Fat, kg/d & 1.74 & 1.70 & 1.73 & 0.08 & 0.89 & 0.71 \\
\hline Protein, \% & 2.80 & 2.90 & 2.73 & 0.06 & 0.38 & 0.10 \\
\hline Protein, kg/d & 1.14 & 1.10 & 1.09 & 0.03 & 0.30 & 0.90 \\
\hline Lactose, \% & 4.69 & 4.75 & 4.78 & 0.06 & 0.28 & 0.85 \\
\hline Lactose, $\mathrm{kg} / \mathrm{d}$ & 1.96 & 1.83 & 1.92 & 0.06 & 0.64 & 0.18 \\
\hline SNF, \% & 8.46 & 8.58 & 8.45 & 0.10 & 0.99 & 0.36 \\
\hline $\mathrm{SNF}, \mathrm{kg} / \mathrm{d}$ & 3.49 & 3.29 & 3.37 & 0.10 & 0.42 & 0.31 \\
\hline $\mathrm{ECM}, \mathrm{kg} / \mathrm{d}$ & 44.8 & 42.9 & 43.4 & 1.6 & 0.52 & 0.62 \\
\hline ECM/DMI & 2.46 & 2.30 & 2.42 & 0.13 & 0.80 & 0.42 \\
\hline MUN, mg/dL & 14.08 & 12.90 & 13.60 & 1.00 & 0.73 & 0.47 \\
\hline
\end{tabular}


Table 5. Concentrations of select metabolites and minerals in serum and urine on the day of calving in cows fed a negative-DCAD diet for 3 $(3 \mathrm{~W}), 4(4 \mathrm{~W})$, or 6 wk $(6 \mathrm{~W})$ prepartum

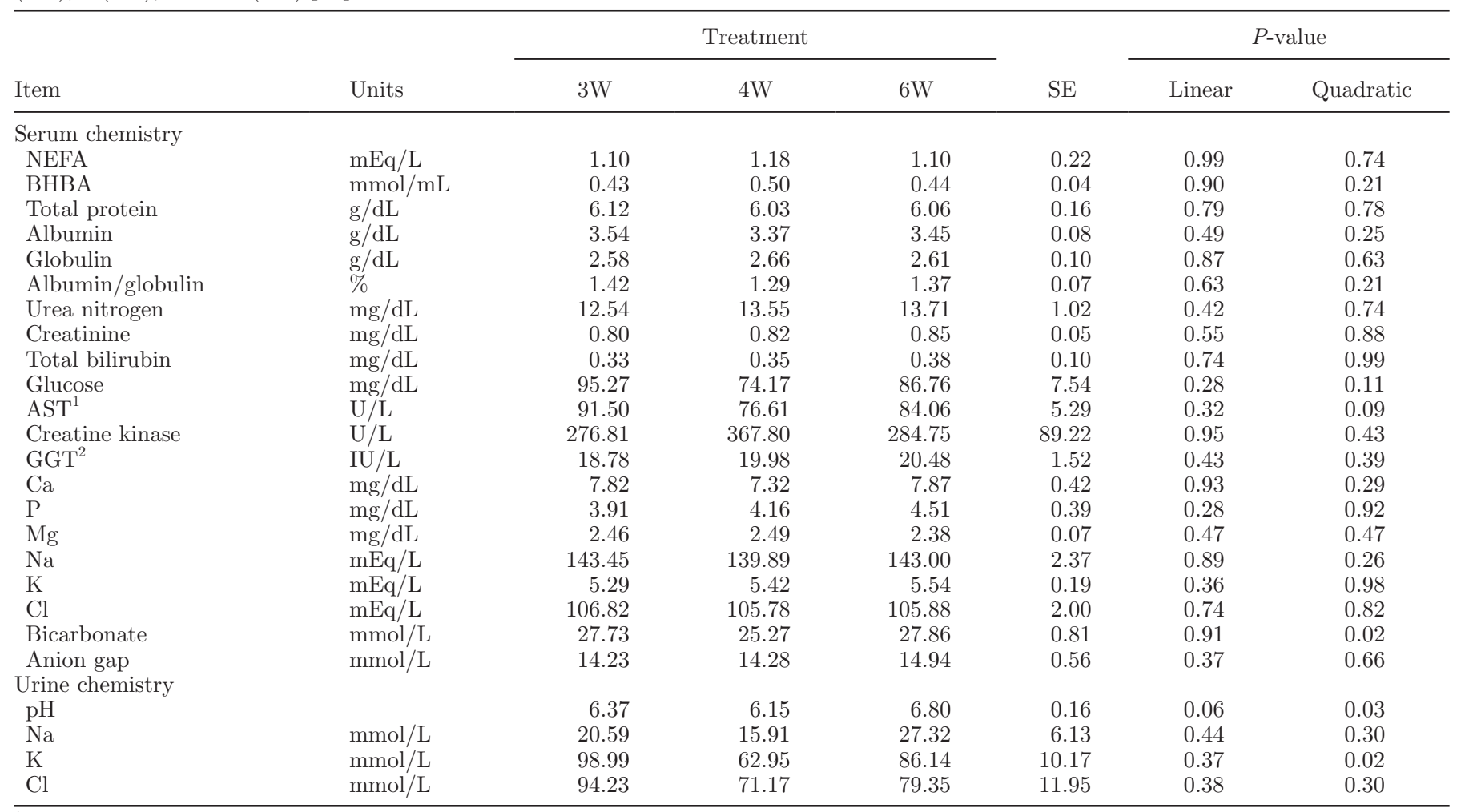

${ }^{1}$ Aspartate transaminase.

${ }^{2} \gamma$-Glutamyl transferase.

(Dauth et al., 1984; Ballantine and Herbein, 1991; Saccon et al., 1995) and should be examined in future trials to monitor actual changes in available serum Ca.

\section{Day-of-Calving Response}

At parturition, a quadratic response was observed for urine $\mathrm{pH}$, which was lower for $4 \mathrm{~W}$ compared with $3 \mathrm{~W}$ and $6 \mathrm{~W}$ (Table 5). Acidification of the blood stimulates parathyroid hormone secretion and initiates bone Ca mobilization and renal production of 1,25-dihydroxyvitamin D, thus increasing Ca level after parturition (Bichara et al., 1990), which would presumably reduce the risk of milk fever or subclinical hypocalcemia. No differences $(P>0.10)$ were observed in serum Ca concentrations on the day of calving for $3 \mathrm{~W}, 4 \mathrm{~W}$, and $6 \mathrm{~W}$, which averaged $7.82,7.32$, and $7.87 \mathrm{mg} / \mathrm{dL}$, respectively. Although cows fed negative-DCAD diets longer than 24 d prepartum had lower concentrations of serum Ca prepartum (Table 3; Figure 3), it does not appear to have negatively affected Ca homeostasis at calving. This is consistent with the report by Weich et al. (2013), who reported increased total serum Ca concentration after parturition for cows fed negative-DCAD diets for $42 \mathrm{~d}$ compared with $21 \mathrm{~d}$.
Based on serum Ca concentrations on the day of parturition, $7.0 \%$ of all cows would be classified as having clinical hypocalcaemia $(<5.5 \mathrm{mg} / \mathrm{dL}), 66.7 \%$ as subclinical hypocalcemic (5.5 to $8.0 \mathrm{mg} / \mathrm{d}$ ), and $26.3 \%$ as normal $(>8.0 \mathrm{mg} / \mathrm{dL})$. The number of cows classified as clinically and subclinically hypocalcemic were higher than expected, given the level of dietary acidification. One possible explanation for this may have been that Ca intake was less than desired. Chan et al. (2006) did not observe any difference in serum $\mathrm{Ca}$ concentration for cows fed diets containing either 0.99 or $1.50 \% \mathrm{Ca}$ and suggested that an intake of approximately $109 \mathrm{~g} / \mathrm{d}$ was adequate based on $11 \mathrm{~kg}$ of DMI/d. In their trial, average milk yield for the first 21 DIM was $21.7 \mathrm{~kg} / \mathrm{d}$. In contrast, prepartum Ca intake averaged $112 \mathrm{~g} / \mathrm{d}$ in our trial and average milk yield during the first $6 \mathrm{wk}$ postpartum was $41.0 \mathrm{~kg} / \mathrm{d}$. Given the higher milk yield, Ca requirements for colostrum production would be higher, so that the $112 \mathrm{~g} / \mathrm{d}$ intake may not have been sufficient and contributed to the lower-than-expected serum Ca concentrations on the day of calving. Serum $\mathrm{Ca}$ concentrations were normal in samples collected during wk 1 to 3 postpartum.

Moore et al. (2000) reported that cows fed a fully acidified diet containing $1.5 \%$ dietary $\mathrm{Ca}$ prepartum 


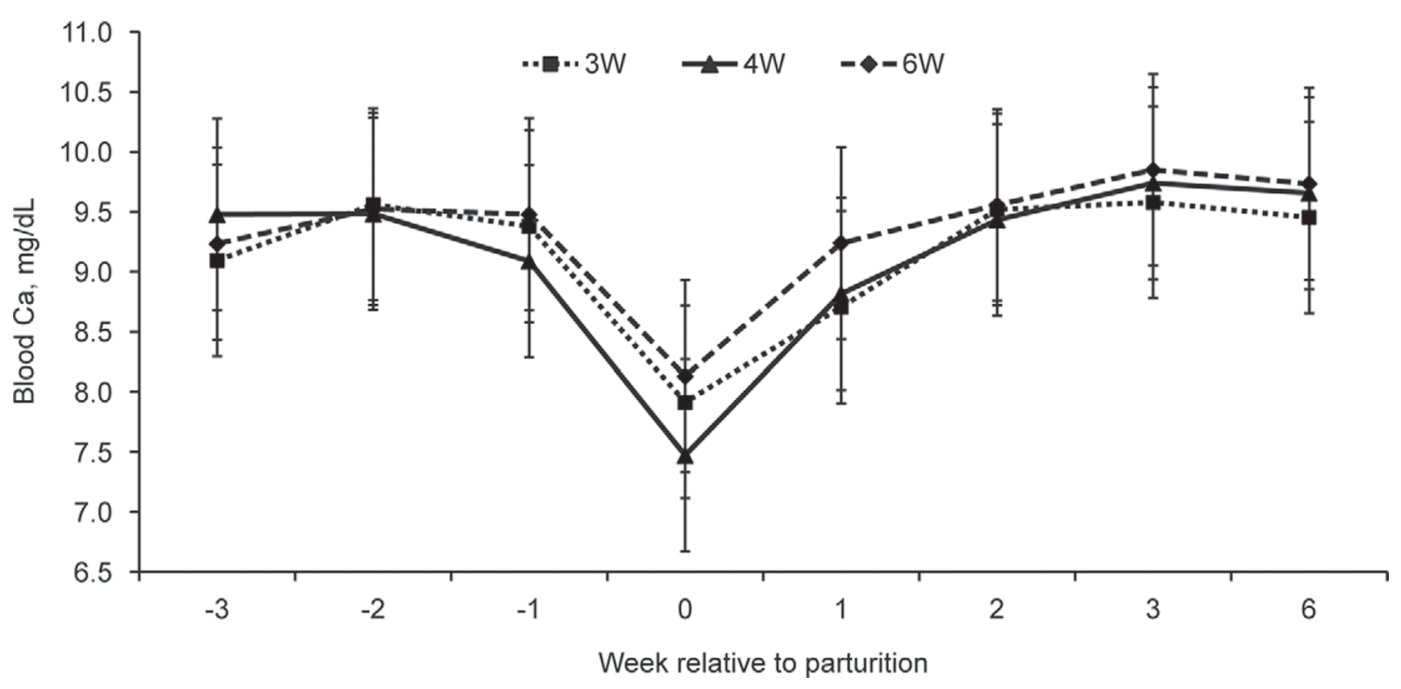

Figure 3. Blood Ca concentrations of cows fed a negative-DCAD diet for $3(3 \mathrm{~W}), 4(4 \mathrm{~W})$, or 6 wk $(6 \mathrm{~W})$ prepartum (treatment $\times$ week: $P$ $>0.10)$. Data represent least squares means \pm SEM.

had higher serum iCa concentrations (4.35 vs. 3.85 $\mathrm{mg} / \mathrm{dL}$ ), resulting in fewer cows classified as clinically hypocalcemic on the day of calving (0 vs. 50\%) compared with cows fed a fully acidified diet containing only $1.0 \%$ dietary Ca prepartum. Oetzel et al. (1988) reported higher $\mathrm{iCa}(4.05$ vs. $3.56 \mathrm{mg} / \mathrm{dL})$ and total serum Ca concentrations ( 8.40 vs. $7.40 \mathrm{mg} / \mathrm{dL}$ ) on the day of calving for cows fed a negative- versus positiveDCAD diet. In addition, Oba et al. (2011) observed that cows fed a negative-DCAD diet $(-6.4 \mathrm{mEq} / 100$ g) with $0.9 \%$ dietary $\mathrm{Ca}$ had faster rates of serum $\mathrm{Ca}$ recovery following an EDTA challenge compared with cows fed the negative-DCAD diet containing 0.3\% Ca. These data suggest that cows fed negative-DCAD diets have improved response to a Ca challenge when higher concentrations of $\mathrm{Ca}$ are fed.

No differences were observed among treatments in concentrations of other serum metabolites or minerals on the day of calving, except for a quadratic response $(P=0.02)$ for bicarbonate, which was lower for $4 \mathrm{~W}$ compared with $3 \mathrm{~W}$ and $6 \mathrm{~W}$ (Table 5 ). However, urine $\mathrm{pH}(P=0.03)$ and $\mathrm{K}$ concentration $(P=0.02)$ exhibited a quadratic response and was lowest for $4 \mathrm{~W}$ compared with $3 \mathrm{~W}$ and $6 \mathrm{~W}$.

\section{Postpartum Response}

Linear increases were observed for postpartum concentrations of serum total protein $(P=0.04)$, globulin $(P=0.02)$, and $\mathrm{Na}(P=0.02)$ with increased time feeding negative-DCAD diets (Table 6). A quadratic response was observed for the ratio of albumin and globulin $(P=0.05)$ because of lower concentrations for $4 \mathrm{~W}$ compared with $3 \mathrm{~W}$ and $6 \mathrm{~W}$. A treatment $\times$ week interaction was observed for postpartum serum GGT concentration $(P=0.01$; Figure 4$)$, and tended to be higher for $4 \mathrm{~W}$ during wk 2 and 3 . No differences were observed in urine $\mathrm{pH}$ and concentrations of minerals among treatments. No differences were observed among treatments in animal health throughout the trial.

Concentrations of serum total protein and globulin were within normal ranges and the increase observed with increasing time that the cows were fed the negative-DCAD diet most likely reflect small differences in protein absorption and metabolism. Serum AST and GGT are frequently used as markers of liver disease resulting from metabolic disease or stress (González et al., 2011; Kataria and Kataria, 2012). Concentrations of AST are used as a sensitive marker of liver damage. In our trial, AST concentrations were within normal ranges, suggesting that the cows did not experience any abnormal hepatic lipidosis (González et al., 2011). The reason for the observed interaction of treatment $\times$ week (Figure 4) is unclear, as GGT concentrations did not increase as much as would be expected with formation of lesions on the liver. González et al. (2011) did not observe any difference in GGT concentrations of cows classified as high (primarily early lactation) or low (primarily mid lactation) lipid mobilization based on serum NEFA and BHBA concentrations.

No differences $(P>0.10)$ were observed between treatments in serum $\mathrm{Ca}$ concentrations postpartum (Figure 3). Recovery of serum Ca concentrations above $8.0 \mathrm{mg} / \mathrm{dL}$ occurred within the first week postcalving. Martinez et al. $(2012,2014)$ reported that cows with serum Ca concentrations below $8.59 \mathrm{mg} / \mathrm{dL}$ within the first $3 \mathrm{~d}$ postpartum had reduced concentrations of neutrophils in the blood, impaired neutrophil function, 


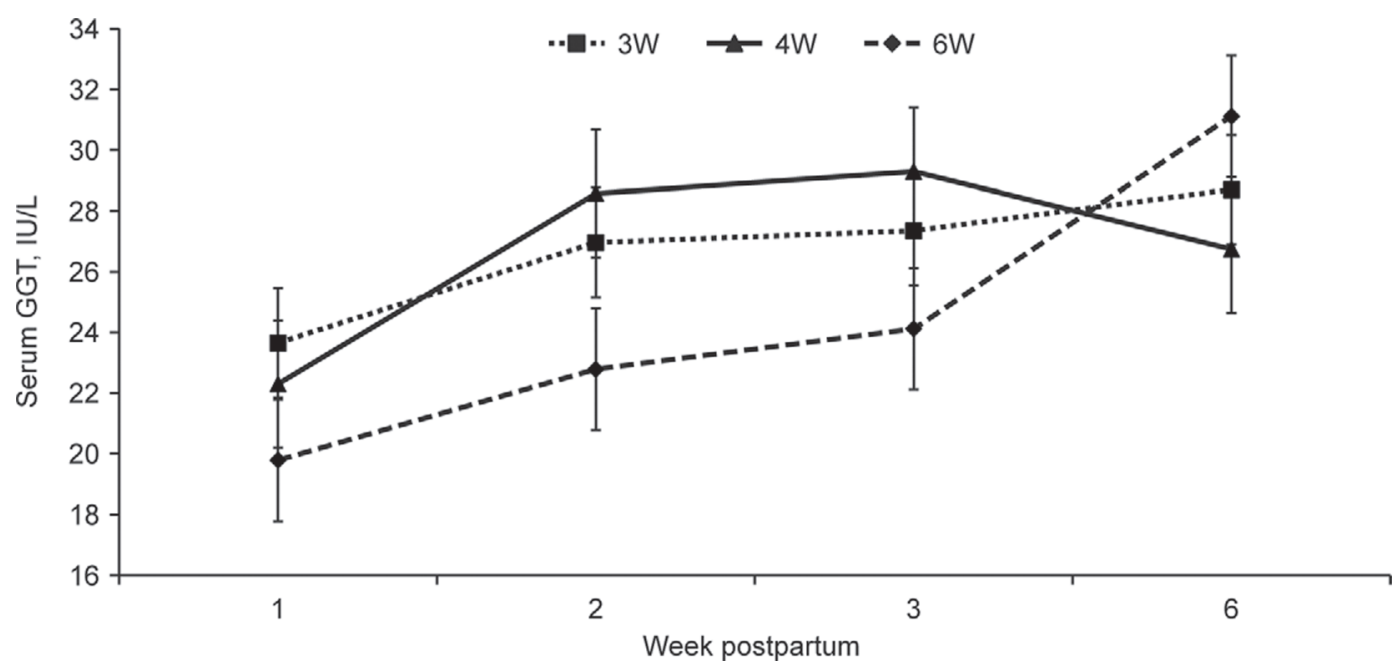

Figure 4. Postpartum serum $\gamma$-glutamyl transferase (GGT) concentrations of cows fed a negative-DCAD diet for 3 (3W), 4 (4W), or 6 wk $(6 \mathrm{~W})$ prepartum (treatment $\times$ week: $P=0.01$ ). Data represent least squares means $\pm \mathrm{SEM}$.

and increased incidence of both metritis and puerperal metritis. Serum Ca concentration of the periparturient dairy cow has 2 dynamics. The first involves the magnitude of decrease in serum Ca concentration following parturition and the second involves the rate of recovery of serum Ca concentration following the initiation of lactation. In our study, the magnitude of decrease in serum Ca concentration comparing wk -1 versus day of calving averaged $1.5 \mathrm{mg} / \mathrm{dL}$. The rate of recovery within 1 wk of calving averaged $1.1 \mathrm{mg} / \mathrm{dL}$. Weich et

Table 6. Concentrations of select metabolites and minerals in serum and urine postpartum (wk 1 through 6 postpartum) in cows fed a negativeDCAD diet for $3(3 \mathrm{~W}), 4(4 \mathrm{~W})$, or $6 \mathrm{wk}(6 \mathrm{~W})$ prepartum

\begin{tabular}{|c|c|c|c|c|c|c|c|}
\hline Item & Units & \multicolumn{3}{|c|}{ Treatment } & $\mathrm{SE}$ & \multicolumn{2}{|c|}{$P$-value } \\
\hline \multicolumn{8}{|l|}{ Serum chemistry } \\
\hline BHBA & $\mathrm{mmol} / \mathrm{mL}$ & 0.60 & 0.51 & 0.75 & 0.09 & 0.19 & 0.20 \\
\hline Total protein & $\mathrm{g} / \mathrm{dL}$ & 6.88 & 7.23 & 7.12 & 0.09 & 0.04 & 0.07 \\
\hline Albumin & $\mathrm{g} / \mathrm{dL}$ & 3.65 & 3.53 & 3.60 & 0.07 & 0.67 & 0.27 \\
\hline Urea nitrogen & $\mathrm{mg} / \mathrm{dL}$ & 15.05 & 14.58 & 14.84 & 1.15 & 0.90 & 0.79 \\
\hline Creatinine & $\mathrm{mg} / \mathrm{dL}$ & 0.67 & 0.67 & 0.63 & 0.02 & 0.27 & 0.52 \\
\hline Total bilirubin & $\mathrm{mg} / \mathrm{dL}$ & 0.30 & 0.31 & 0.30 & 0.03 & 0.82 & 0.73 \\
\hline Glucose & $\mathrm{mg} / \mathrm{dL}$ & 50.34 & 53.81 & 50.00 & 1.75 & 0.89 & 0.13 \\
\hline $\mathrm{AST}^{1}$ & $\mathrm{U} / \mathrm{L}$ & 109.92 & 97.93 & 103.38 & 4.82 & 0.31 & 0.21 \\
\hline Creatine kinase & $\mathrm{U} / \mathrm{L}$ & 143.67 & 179.48 & 152.87 & 22.96 & 0.76 & 0.34 \\
\hline $\mathrm{GGT}^{2}$ & $\mathrm{IU} / \mathrm{L}$ & 26.67 & 26.73 & 24.45 & 1.57 & 0.29 & 0.60 \\
\hline $\mathrm{Cl}$ & $\mathrm{mEq} / \mathrm{L}$ & 96.77 & 95.67 & 95.51 & 0.86 & 0.13 & 0.40 \\
\hline Bicarbonate & $\mathrm{mmol} / \mathrm{L}$ & 32.96 & 32.51 & 32.98 & 0.57 & 0.98 & 0.56 \\
\hline Anion gap & $\mathrm{mmol} / \mathrm{L}$ & 16.47 & 15.78 & 16.20 & 0.33 & 0.55 & 0.23 \\
\hline \multicolumn{8}{|l|}{ Urine chemistry } \\
\hline $\mathrm{pH}$ & & 8.21 & 8.18 & 8.22 & 0.05 & 0.95 & 0.62 \\
\hline $\mathrm{Na}$ & $\mathrm{mmol} / \mathrm{L}$ & 91.72 & 98.44 & 92.51 & 7.72 & 0.94 & 0.56 \\
\hline $\mathrm{K}$ & $\mathrm{mmol} / \mathrm{L}$ & 146.66 & 146.80 & 131.90 & 9.49 & 0.26 & 0.55 \\
\hline $\mathrm{Cl}$ & $\mathrm{mmol} / \mathrm{L}$ & 37.24 & 38.67 & 35.34 & 3.30 & 0.67 & 0.58 \\
\hline
\end{tabular}

${ }^{1}$ Aspartate transaminase

${ }^{2} \gamma$-Glutamyl transferase. 


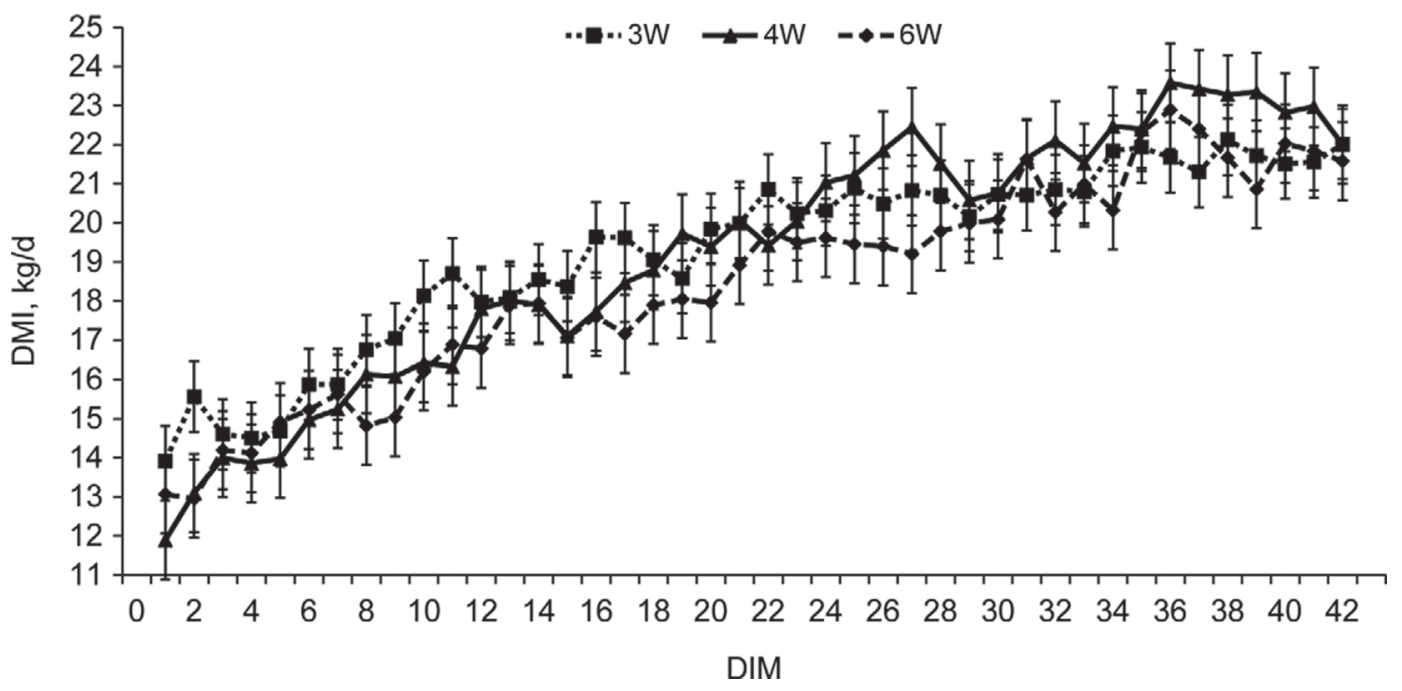

Figure 5. Postpartum DMI of cows fed a negative-DCAD diet for $3(3 \mathrm{~W}), 4(4 \mathrm{~W})$, or 6 wk $(6 \mathrm{~W})$ prepartum (treatment $\times$ day: $P>0.10)$. Data represent least squares means \pm SEM.

al. (2013) observed no increase in total serum Ca concentration for any treatment groups (control, positive DCAD prepartum, negative DCAD prepartum for 21 $\mathrm{d}$, or negative DCAD prepartum for $42 \mathrm{~d}$ ) between 12 and $24 \mathrm{~h}$ postcalving. However, by $72 \mathrm{~h}$, increases in total serum $\mathrm{Ca}$ were observed but these values were still below $8.0 \mathrm{mg} / \mathrm{dL}$, a concentration that has been used for many years as the expected normal serum Ca concentration for periparturient dairy cows. In contrast to total serum Ca concentration, Weich et al. (2013) reported higher concentrations of $\mathrm{iCa}$ in serum postcalving. Oetzel et al. (1988) also reported different responses between total serum $\mathrm{Ca}$ and iCa in periparturient dairy cows fed ammonium chloride and ammonium sulfate. In that study, total serum Ca concentration was a better predictor of Ca status on the day before calving, whereas iCa concentration was a better predictor of $\mathrm{Ca}$ status on the day of calving. Those studies demonstrate that differences between total serum Ca concentration and ionized serum Ca concentration may exist and that interpretation of data by one of these measures may differ from and potentially contradict interpretation of the data using the other measure.

Daily DMI postpartum was not different among treatments $(P>0.10$; Figure 5$)$. No differences among treatments were observed in average postpartum DMI,

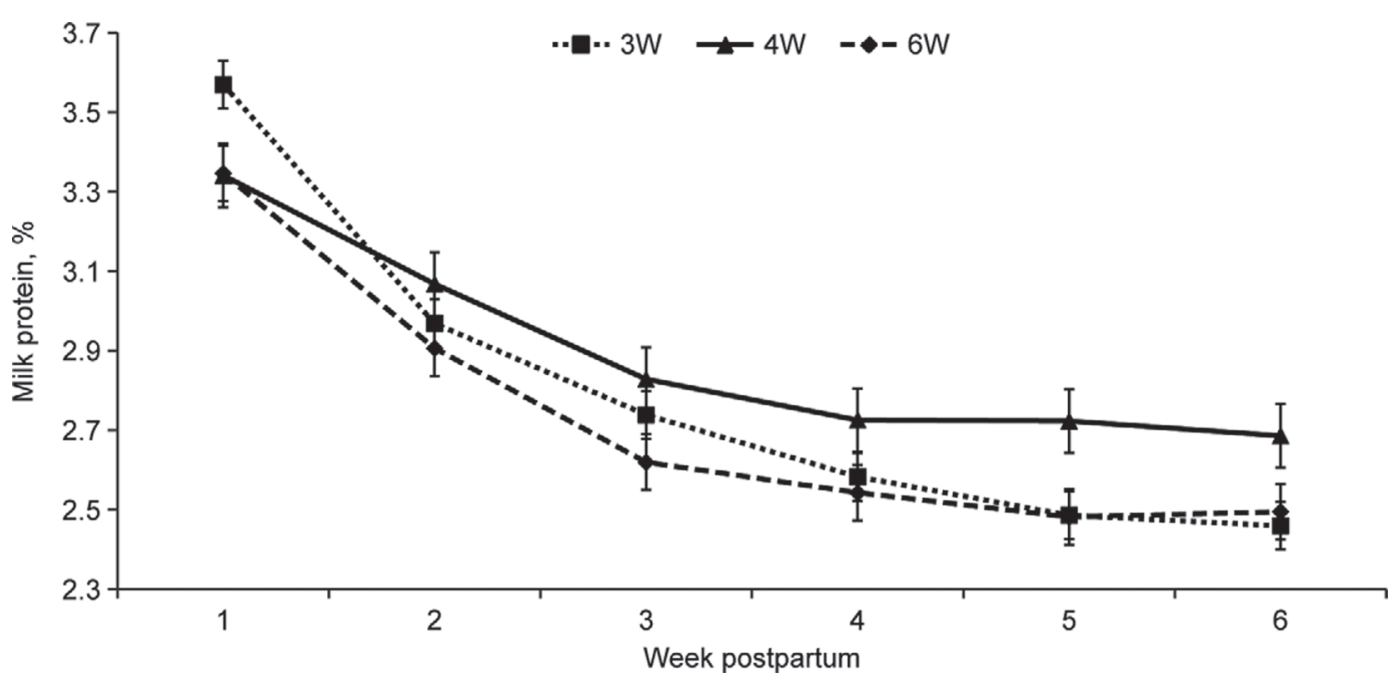

Figure 6. Milk protein percentage of cows fed a negative-DCAD diet for $3(3 \mathrm{~W}), 4(4 \mathrm{~W})$, or 6 wk $(6 \mathrm{~W})$ prepartum (treatment $\times$ week: $P=$ 0.0001). Data represent least squares means \pm SEM. 


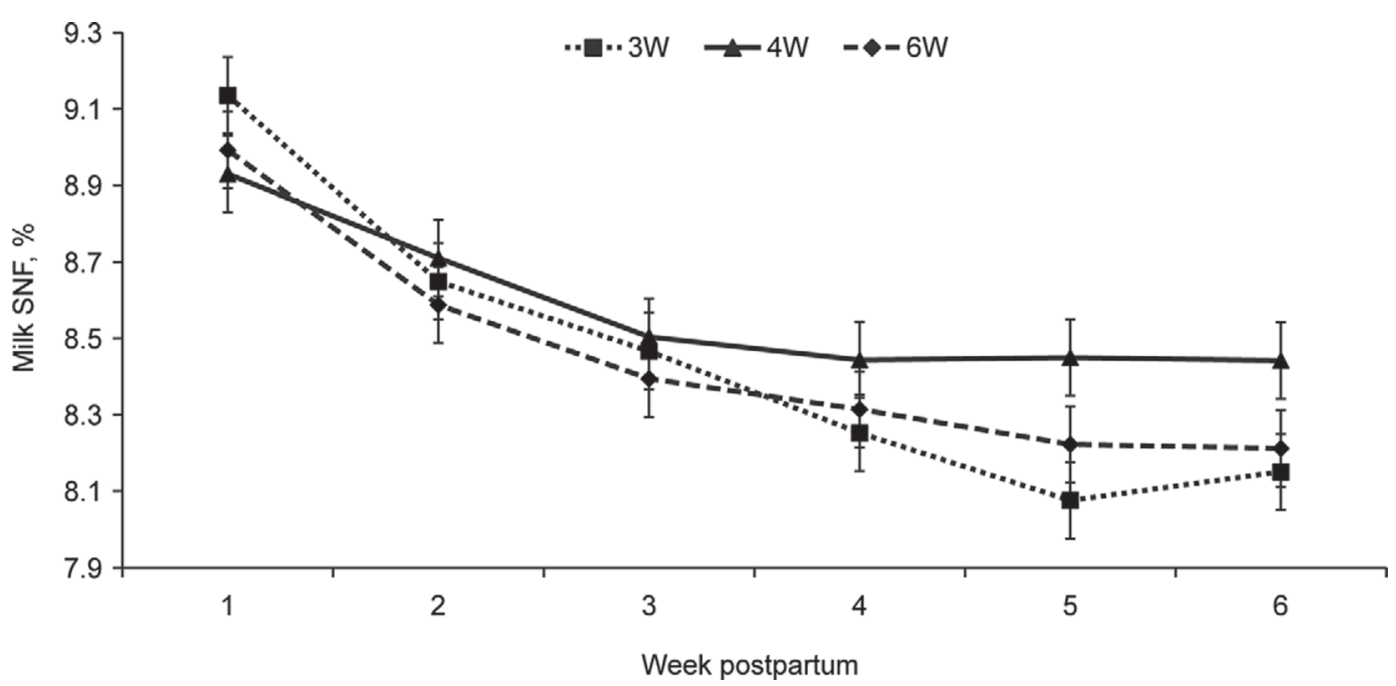

Figure 7. Milk SNF percentage of cows fed a negative-DCAD diet for $3(3 \mathrm{~W}), 4(4 \mathrm{~W})$, or 6 wk $(6 \mathrm{~W})$ prepartum (treatment $\times$ week: $P=$ 0.01). Data represent least squares means \pm SEM.

yield and percentage of milk, milk fat, lactose, or SNF (Table 4). Milk protein percentage tended to be higher for $4 \mathrm{~W}$ compared with $3 \mathrm{~W}$ and $6 \mathrm{~W}$ (quadratic effect: $P=0.10)$. An interaction of treatment $\times$ week for milk protein $(P=0.0001$; Figure 6$)$ was detected, with higher percentage for $3 \mathrm{~W}$ compared with $4 \mathrm{~W}$ and $6 \mathrm{~W}$ during wk 1 and higher percentage for $4 \mathrm{~W}$ compared with $3 \mathrm{~W}$ and $6 \mathrm{~W}$ during wk 5 and 6 . Milk SNF percentage exhibited an interaction of treatment $\times$ week and was higher $(P=0.01$; Figure 7$)$ for $4 \mathrm{~W}$ during wk 5 compared with $3 \mathrm{~W}$ and $6 \mathrm{~W}$. No differences $(P>$ 0.10) were observed in ECM yield, efficiency (ECM/ DMI), or MUN concentrations among treatments.

The higher milk protein percentage and SNF percentage observed for $4 \mathrm{~W}$ is consistent with the higher serum total protein and globulin concentrations. The increased serum protein concentration observed postpartum suggested an upregulation of metabolism following increased exposure to negative-DCAD diets (DeGaris et al., 2010).

Results of this trial indicate that feeding a negativeDCAD diet for increasing lengths of time before calving may slightly decrease concentrations of total serum protein, albumin, $\mathrm{Ca}$, and $\mathrm{K}$, and anion gap prepartum and support linear increases in serum total protein, globulin, and $\mathrm{Na}$ postpartum. The changes in $\mathrm{K}$ and $\mathrm{Na}$ concentrations and anion gap most likely reflect changes in response to dietary supplementation and homeostasis. The slight decrease in serum Ca concentration prepartum observed with increased length of feeding the negative-DCAD diet did not affect serum $\mathrm{Ca}$ on the day of calving or postpartum. The changes in milk protein possibly reflect differences in protein balance, which supported slightly higher milk protein percentages for cows fed negative-DCAD diets for $4 \mathrm{wk}$ before calving. Overall, the results of the trial indicate minor differences in serum metabolite concentrations and urinary excretion of minerals as a result of feeding a negative-DCAD diet for 3, 4, or 6 wk before calving, but the effects do not appear to alter cow health or performance postpartum. These data suggest that feeding a negative-DCAD diet for longer than the traditional feeding period of $21 \mathrm{~d}$ prepartum does not negatively affect cow health or performance. These results are consistent with previous research documenting the effects of extended feeding of negative-DCAD diets (Block, 1984; Weich et. al., 2013). From an applied application standpoint, these collective data support the use of negative-DCAD diets in 1-group dry cow programs.

\section{REFERENCES}

AOAC International. 2000. Official Methods of Analysis. 17th ed. AOAC International, Arlington, VA.

Ballantine, H. T., and J. H. Herbein. 1991. Potentiometric determination of ionized and total calcium in blood plasma of Holstein and Jersey cows. J. Dairy Sci. 74:446-449.

Bichara, M., O. Mercier, P. Borensztein, and M. Paillard. 1990. Acute metabolic acidosis enhances circulating parathyroid hormone, which contributes to the renal response against acidosis in the rat. J. Clin. Invest. 86:430-443.

Block, E. 1984. Manipulating dietary anions and cations for prepartum dairy cows to reduce incidence of milk fever. J. Dairy Sci. 67:2939-2948.

Chan, P. S., J. W. West, and J. K. Bernard. 2006. Effect of prepartum dietary calcium on intake and serum and urinary mineral concentrations of cows. J. Dairy Sci. 89:704-713.

Curtis, C. R., H. N. Erb, C. J. Sniffen, R. D. Smith, and D. S. Kronfeld. 1985. Path analysis of dry period nutrition, postpartum metabolic and reproductive disorders, and mastitis in Holstein cows. J. Dairy Sci. 68:2347-2360.

Dauth, J., M. J. Dreyer, and J. P. de Coning. 1984. Ionized calcium versus total calcium in dairy cows. J. S. Afr. Vet. Assoc. 55:71-72. 
Degaris, P. J., I. J. Lean, A. R. Rabiee, and C. Heuer. 2008. Effects of increasing days of exposure to prepartum transition diets on milk production and milk composition in dairy cows. Aust. Vet. J. 86:341-351.

DeGaris, P. J., I. J. Lean, A. R. Rabiee, and M. A. Stevenson. 2010. Effects of increasing days of exposure to prepartum diets on the concentration of certain blood metabolites in dairy cows. Aust. Vet. J. 88:137-145.

DeGroot, M. A., E. Block, and P. D. French. 2010. Effect of prepartum anionic supplementation on periparturient feed intake, health, and milk production. J. Dairy Sci. 93:5268-5279.

DuBois, M., K. A. Giles, J. K. Hamilton, P. A. Rebers, and F. Smith. 1956. Colorimetric method for determining sugars and related substrates. Anal. Chem. 28:350-356.

González, F. D., R. Muiño, V. Pereira, R. Campos, and J. L. Benedito. 2011. Relationship among blood indicators of lipomobilization and hepatic function during early lactation in high-yielding dairy cows. J. Vet. Sci. 12:251-255.

Hall, M. B. 2009. Analysis of starch, including maltooligosaccharides, in animal feeds: A comparison of methods and a recommended method for AOCB collaborative study. J. AOAC Int. 92:42-49.

Kataria, N., and A. K. Kataria. 2012. Use of serum gamma glutamyl transferase as a biomarker of stress and metabolic dysfunction in Rathi cattle of arid tract in India. J. Stress Physiol. Biochem. $8: 23-29$.

Martinez, N., C. A. Risco, F. S. Lima, R. S. Bisinotto, L. F. Greco, E. S. Ribeiro, F. Maunsell, K. Galvão, and J. E. P. Santos. 2012. Effect of peripartal calcium status, energetic profile, and neutrophil function in dairy cows at low or high risk of developing uterine disease. J. Dairy Sci. 95:7158-7172.

Martinez, N., L. D. P. Sinedino, R. S. Bisinotto, E. S. Ribeiro, G. C. Gomes, F. S. Lima, L. F. Greco, C. A. Risco, K. N. Galvão, D. Taylor-Rodriguez, J. P. Driver, W. W. Thatcher, and J. E. P. Santos. 2014. Effect of induced subclinical hypocalcemia on physiological responses and neutrophil function in dairy cows. J. Dairy Sci. 97:874-887.

Moore, S. J., M. J. VandeHaar, B. K. Sharma, T. E. Pilbeam, D. K. Beede, H. F. Bucholtz, J. S. Liesman, R. L. Horst, and J. P.
Goff. 2000. Effects of altering dietary cation-anion difference on calcium and energy metabolism in peripartum cows. J. Dairy Sci. 83:2095-2104.

NRC. 2001. Nutrient Requirements of Dairy Cattle. 7th rev. ed. Natl. Acad. Press., Washington, DC.

Oba, M., A. E. Oakley, and G. F. Tremblay. 2011. Dietary Ca concentration to minimize the risk of hypocalcemia in dairy cows is affected by the dietary cation-anion difference. Anim. Feed Sci. Technol. 164:147-153.

Oetzel, G. R., J. D. Olson, C. R. Curtis, and M. J. Fettman. 1988. Ammonium chloride and ammonium sulfate for prevention of parturient paresis in dairy cows. J. Dairy Sci. 71:3302-3309.

Payne, R. B., M. E. Carver, and D. B. Morgan. 1979. Interpretation of serum total calcium: Effects of adjustment for albumin concentration on frequency of abnormal values and on detection of change in the individual. J. Clin. Pathol. 32:56-60.

Puntenney, S. 2006. The effect of prepartum anionic diets on cortisol, adiponectin, and tumour necrosis factor- $\alpha$ expression at varying levels of body mass index in preparturient dairy Cows: Implications for insulin resistance. PhD Dissertation. Oregon State University, Corvallis.

Saccon, N., F. Agnes, S. Dominoni, and P. Camussone. 1995. Metabolic profile of dairy cows from the first fecundation to the peak of the second lactation. Archivio Veterinario Italiano (Italy) 46:49-56.

Van Soest, P. J., J. B. Robertson, and B. A. Lewis. 1991. Methods for dietary fiber, neutral detergent fiber, and nonstarch polysaccharides in relation to animal nutrition. J. Dairy Sci. 74:3583-3597.

Weich, W., E. Block, and N. B. Litherland. 2013. Extended negative dietary cation-anion difference feeding does not negatively affect postpartum performance of multiparous dairy cows. J. Dairy Sci. 96:5780-5792.

Wildman, E. E., G. M. Jones, P. E. Wagner, R. L. Boman, H. F. Troutt Jr., and T. N. Lesch. 1982. A dairy cow body condition scoring system and its relationship to selected production characteristics. J. Dairy Sci. 65:495-501. 